\title{
Epidemiology of HIV/AIDS infected persons in the western part of Romania in 2013
}

\author{
Voichița Lăzureanu ${ }^{1 *}$, Teodora Moisil ${ }^{22}$, Virgil Musta ${ }^{1}$, Maria Cerbu $^{22}$, Emilia Nicoară', Narcisa Nicolescu', \\ Ruxandra Laza', Alexandru Crişan ${ }^{1}$ \\ From The 7th Romanian National HIV/AIDS Congress and The 2nd Central European HIV Forum \\ Sibiu, Romania. 29-31 May 2014
}

HIV transmission continues in Romania, despite decades of concerned efforts to inform the public about HIV and its consequences and reduce individual risk behaviors.

This is a retrospective study carried out in 2013 in the western part of Romania, in the counties Arad, CaraşSeverin, Hunedoara and Timiş.

In 2013 there are 846 patients with HIV/AIDS in active evidence, $86.4 \%$ in combined antiretroviral therapy (cART). Despite intense counseling, 30 (4.1\%) patients interrupted willingly their antiretroviral therapy. There are 93 new infected persons in 2013, mostly men who have sex with men (MSM). 10 children were born in 2013 from HIV infected mothers, 1 was diagnosed while pregnant, 1 at delivery, 8 were known with HIV/AIDS prior to pregnancy. All 10 newborns received prophylaxis with antiretrovirals for 6 weeks. 11 (1.33\%) patients were diagnosed with tuberculosis, 10 with pulmonary tuberculosis and 1 with tuberculous meningoencephalitis.

HIV/AIDS infection remains an important public health problem in the Western part of Romania.

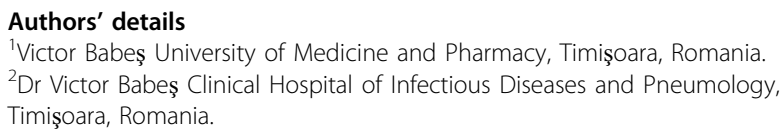

${ }^{1}$ Victor Babeş University of Medicine and Pharmacy, Timişoara, Romania. ${ }^{2}$ Dr Victor Babeş Clinical Hospital of Infectious Diseases and Pneumology, Timişoara, Romania.

Published: 29 May 2014

doi:10.1186/1471-2334-14-S4-P24

Cite this article as: Lăzureanu et al:: Epidemiology of HIV/AIDS infected persons in the western part of Romania in 2013. BMC Infectious Diseases 2014 14(Suppl 4):P24.

${ }^{1}$ Victor Babeş University of Medicine and Pharmacy, Timişoara, Romania Full list of author information is available at the end of the article

Submit your next manuscript to BioMed Central and take full advantage of:

- Convenient online submission

- Thorough peer review

- No space constraints or color figure charges

- Immediate publication on acceptance

- Inclusion in PubMed, CAS, Scopus and Google Scholar

- Research which is freely available for redistribution
C Biomed Central

C 2014 Lăzureanu et al; licensee BioMed Central Ltd. This is an Open Access article distributed under the terms of the Creative Commons Attribution License (http://creativecommons.org/licenses/by/4.0), which permits unrestricted use, distribution, and reproduction in any medium, provided the original work is properly cited. The Creative Commons Public Domain Dedication waiver (http://creativecommons.org/publicdomain/zero/1.0/) applies to the data made available in this article, unless otherwise stated. 